\title{
Assessment in Architectural Design Education Case Study: First-Year Students at Pharos University
}

\author{
Ghada Ahmed Ragheb \\ Department of Architectural Engineering, Pharos University, Alexandria 21311, Egypt
}

\begin{abstract}
Effective assessment is inseparable from good teaching and learning. Just as a good tutor would practice different techniques of teaching, an assessor would usually use different strategies of assessment. Moreover, the different activities of assessment, such as teaching, are additionally executed at various times during the semester, thus, we can know in which way the student is learning. An assessment strategy lays out a well thoroughly considered choice of assessment methods that are aligned with the aims and learning outcomes. Because align the assessment with a specific kind of learning outcome, the tutor needs to choose a suitable technique of assessment. This paper draws upon a case study of the first year architectural design at Pharos University as another way to deal with realizing "how to design your assessment plan". Throughout the form of criteria based assessment, assessment can help to review the students and instructors feeling and reactions. Finally, we can learn to assist towards enhancing student learning through assessment. So, we can attract the consideration regarding the advantages of reviewing current assessment practices, and of accepting different ways to deal with assessment methods, in this manner profiting together student and tutor.
\end{abstract}

Key words: Constructive alignment, assessment for learning, criteria-based assessment.

\section{Introduction}

The role of assessment is shifting. Assessment as of now sees as a method to improve learning as opposed to monitoring it, thus, assessment is for learning. Assessment for learning is the process of searching and understanding indication for practice by students and instructors to determine the level of learners in their learning, the target which they have to go towards and how best to arrive.

Design education in the first year course is the main determinant of the most critical chances for students to acquire abilities and data that establish the base for continuous development in later years. For decades, schools of architecture have subscribed the project review as a form of teaching and assessment which was an effective method of transmitting the information and skills of the architect to the next generation of the profession. Also in the design studio, we can reflect more than the functional effectiveness

Corresponding author: Ghada Ahmed Ragheb, assistant professor, research fields: architectural education and heritage. by the permanence of a social environment. The crucial part of architecture design studios is the usage of inherited models and method of assessment [1].

Given that what students learn is so strongly related to how they learn, the modes of delivery and assessment that we as teachers provide them with, have a major impact on their ability to learn [2].

\section{Methodology}

This paper tries to align first-year architectural design course assessment with its intended learning outcomes. In order to achieve the postulated aim, this paper traces the following steps:

- Defining important terms related to the assessment process (constructive alignment and assessment for learning);

- Discuss the methods in which studio tutors evaluate students' work and performance during the work studios;

- Review the assessment for learning strategies and method of criteria-based grading/models;

- Present and discuss the case study of the first 
year architectural design at Pharos University with the aim of learning "how to design your assessment plan";

- Design a form of criteria based assessment using a learning outcomes approach and distinguish the requirement of strategy assessment as the main part of an entire course experience so as to align with the objectives, learning outcomes and with the teaching/learning methods adopted.

\section{What Is Constructive Alignment?}

CA (constructive alignment) is such a system. It is a way to deal with an educational design that improves the conditions for quality learning. It has two aspects.

"The (constructive) aspect refers to what the learner does, which is to construct meaning through relevant learning activities. The "alignment" aspect refers to what the teacher does, which is to set up a learning environment that supports the learning activities appropriate to achieving the desired learning outcomes. The key is that the components in the teaching system, especially the teaching methods used and the assessment tasks are aligned to the learning activities assumed in the intended outcomes. The learner is in a sense 'trapped', and finds it difficult to escape without learning what is intended should be learned" [3].

In this guide, let's concentrate on aligning a semester length and content. There are four major steps:

(1) Defining the intended learning outcomes;

(2) Choosing teaching/learning objectives;

(3) Assessing students' learning outcomes to know how well they match what was intended;

(4) Arriving at a final grade (aligning teaching).

Constructive alignment in project-based learning gives the chance to entrap students in a web of consistency. While the central design of a curriculum can incorporate the core elements of a syllabus for successful alignment, thought of pace and timing of content delivery, assessment and learning chances can improve student engagement and satisfaction [4].

\section{Assessment for Learning}

Assessment is a term used to describe the estimation of students' growth and achievements, the quality of their learning and diagnosing misunderstandings. By knowing exactly what students know and do not know, assessment can be used as an approach to teaching more effectively.

"Assessment should be used to encourage deep learning 'the relevance and importance of what they are required to do to achieve intended learning outcomes. The most important impacts on the students learning approach are the assessment strategies used [5]. Therefore, assessment tasks should reflect realistic problems whenever possible to encourage deep learning [6]. Thus, in defining intended learning outcome, tutors have to identify the topic content and the level of understanding that we want our students to achieve [3]. So, we design an assessment task that will inform us whether they have aligned and achieved the intended learning outcomes."

When the clear expectations are set, reasonable workloads are established, chances for students to self-monitor are given, review, training, and feedback exist, there is a powerful assessment. The assessment must be seen as a part of the teaching-learning process instead of a comparison between the students. When the assessment is well-designed, it will directly contribute to the way students conduct their study. But when the assessment is poorly designed, it has possible to delay learning and distort the track of growth. As such, assessment indirectly contributes but efficiently to the quality of teaching and learning process [7].

It is important in education to tell the learners, about their strengths and weakness, what they have to do to enhance their useful abilities, the value of their thoughts, technical understanding, and their capability to search and understand their targets [8].

To facilitate assessment process, rubric or grading criteria must be made clear and public. So that student can better understand lecturer's expectations. Also, 
timely and good feedback, related to criteria-based assessment, is vital to motivate student engagement to avoid the limited effect [9].

\section{Types of Assessment in the Architectural Design Studios}

One of the main characteristics of the design education is that its assessment is not based on formal examinations. It can conduct in studios by indirect ways through practice and projects (the evaluation of student achievement, knowledge, and skill).

Architectural education contains together summative and formative assessment methods. Formative assessment methods are used as a teaching strategy especially in reviewing and also give feedback to the learners on their work.

Design studio assessment includes both the criterion-referenced assessment, as the instructors need to see that student qualify certain standards in order to pass to upper level; and "the norm-referenced assessment, as the particular grades of the students depends on the quality of the product" [10]. The assessments can be informal and formal and the grades can be given both by the internal and the external evaluator.

Since the beginning of architectural education, project criticisms have been applied in the formal education and that cannot be abandoned. Today, there are different categories of reviewing which are applied in design studios. The first category is "individual criticism" between the student and instructor. It comes after the establishment of common criteria and is preferred in long time projects. Individual criticisms are quite effective for following the personal progress of learners in their design studies.

The second category which is critical at the start of the design learning is "panel discussion". The panel is executed by discussing the projects which are chosen haphazardly by the tutors without knowing which student it belongs to. These discussions, which are carried out interactively in a participatory environment, are successful mediums of learning.

This format gives feedback to the students by the indirect way and averts the critic to be taken personally. The other category may be the most formal way of the review is design jury. In the jury system, one student or a group of students present/defend their work in front of the jury and get feedback/criticism. The jury is the most performative stage of education where student and instructors actually interact. It carries out both assessment and education of students jointly [10].

\section{Assessment for learning Strategies}

According to Peter Holgate and the CETL (Centre for Excellence in Teaching and Learning) at the University of Northumbria, there are six conditions which have been identified as a key to the successful implementation of "assessment for learning" in learning environments [11].

\subsection{Emphasizes Authenticity and Complexity in} Methods of Assessment

"Problem-based learning reflects how people learn in real life. The pioneers define problem-based learning as the learning that results from the process of working towards the understanding or resolution of a problem. The problem is first encountered in the learning process, and it serves as a focus or stimulus for the application of problem-solving, as well as for the search for or study of information or knowledge needed to understand the mechanisms responsible for the problem and how it might be resolved" [12].

In the architectural design project, authenticity and complexity are essential in the guidelines issued to the learners which reflect true professional practice. Therefore, design assignments are delivered to promote "problem-based learning". It must provide an architectural brief about the project with a specific program, and learners are set the mission of providing a design solution of "commodity, firmness, and 
delight". This reflects authentic architectural practice. However, in the learning environment of the university design studio, additional time can be devoted to the process by which the design solution is improved rather than speed up the final outputs [11].

\subsection{Use of Summative Assessment as the Main Driver for Learning}

Use the summative assessment at the end of the design process and the assessment criteria are made clear to the students throughout the broad opportunities for formative assessment during the course of the design project. "Summative assessment is based upon the collective output of the preceding weeks of formative assessment and feedback. A portfolio submission is required which, together with the final proposals, collects and demonstrates all the developmental work by the student-sketch models, diagrams, initial and scheme designs thus providing clear evidence of the student's learning journey from the project's inception to completion" [11]. Tutors express that the critics are to show students how to assess, reflect on their work and improve their own critical judgment, not be told what is wrong or right. The aim of the critique should be clarified to students [13].

\subsection{Extensive Opportunities to Develop and Demonstrate Learning}

"The weekly chances are given to the students to improve and demonstrate the skills of learning that will be required to complete the summative assessment". A useful and authentic technique used to suggestion the development of the students' learning is a digital presentation of the scheme, which describes the development of the proposals leading up to the tutorial or review at that time [11].

\subsection{Rich in Formal Feedback}

Following the introduction the brief, the student is tasked with the production of initial concepts for discussion the following week. "Tutors provide weekly sheets for the students which stipulate the tasks that the students should address in the week ahead, and benchmark the expected level of progress of students within the cohort. The iterative process of the studio tutorial allows the tutor to monitor the student progress effectively; any misunderstandings in communications or expectations can be attended to at the following session"; in the best cases, the student feels comfortable being allowed to "make mistakes" and learn from these, without the risk of great penalty in the summative assessment; week by week contact with the tutors lets for direct recovery when issues happen. The formative assessment and learning strategies are in this way inseparably interlinked, the criticism effectively impacting the strategy. "Formal feedback, from different tutors and practitioners, is given at intermediate reviews in written form. The upkeep of a reflective logbook is encouraged, this practice being stipulated as part of the students' portfolio submissions. Studio design projects concluded with a final review which will assign relevant feedback to the project learning outcomes as a final summation of the work which needs to be addressed" [11].

\subsection{Rich in Informal Feedback}

"In the past design, tutors used their professional judgment alone to judge student performance. However, the use of hidden criteria may not be particularly useful to student learning. The ability of tutors to communicate hidden assessment criteria clearly is a critical factor to the success of continual formative assessment; typical examples of such criterion in architectural design may include the use of standard graphic representations" (e.g., the use of arrows to denote an entrance on plan); care in graphical communications (ensuring plans and elevations are centrally located in drawings, horizontally aligned etc.); clarity of design intent; student ability to communicate a narrative; care and attention (binding drawings together chronologically 
to show the development of a scheme) [14]. "Teachers should be aware of the impact that comments, marks and grades can have on learners' confidence and enthusiasm and should be as constructive as possible in the feedback that they give". Comments that focus on the work rather than the person are more constructive for both learning and motivation, the experience of being assessed is interpreted as both positive and negative in its impact. In some cases, the interaction between the learner and the assessment event is so negative that it has an emotional impact that lasts many years. Assessment appeared to be intimately connected to identity. Experiences were taken personally [11].

\subsection{Developing Students' Abilities to Direct Their Own} Learning, Evaluate Their Own Progress and Support the Learning of Others

Many forms of group and teamwork have the power to encourage co-operation, two stand out as most useful and powerful: peer tutoring and student involvement in assessment. The architectural teaching has great possible for the inclusion of peer assessment. Peer tutoring is seen as "particularly relevant when one seeks to maximize the student's responsibility for his own learning". "The extensive formative feedback provided through a design project allows students to direct their own learning; reviews, tutorials and studio presence and training allow students rich opportunities for peer learning and self-assessment" [11].

The learning environment of the design studio provides a constant source of current information for student self-evaluation. The progress of peers is evidenced on the display walls and drawing boards of the studio - as aforementioned, allowing a student to identify any shortfalls and learn from peers. This self-evaluation is reinforced by the staff provision of weekly progress sheets to students of the lower years which clarifies the output expectations of the week ahead. This sheet also provides a checklist of what the student should have achieved to date.

\section{Method of Criteria-Based Grading/Models}

Assessment includes identification of aims and goals, the election of processes, measures, and methods, analysis of data, management of schedule, interpretation of outcomes, and formulation of responses to the outcomes. Of major significance in any assessment is an election of criteria on which to base the assessments.

Since criteria are attributes that are beneficial for making judgments, it is valuable to have a broad meaning of what criterion is. Grading models sometimes designed to cover all course or otherwise on specific assessment tasks and some can be suitable for both. For all different grading models, the understanding of criteria makes a clear linking between the success for course objectives and given grades, without reference to other students achievements [15].

"Main aims that were the basis of the problem-solving process are the greatest significant part of assessment. So the criteria to be used in assessment and grading are related directly to the way objectives expressed. Since this approach has some conceptual parallels with the behavioral objectives movement, a behavioral objective is not properly formulated unless it includes a statement of intent, descriptions of the final behavior desired, the conditions under which this behavior is to be demonstrated and the minimum acceptable level of performance that signifies achievement of that objective" [13].

"The quality of student's work together with interpretations of such judgments can be known as a comprehensive model in judgments. So alternatively, a simple oral scale could be used for each criterion such as fail, poor, average, good, and excellent, but in this type, verbal grade description applies to given assessment task, with a separate description for each grade level. So each list of criteria can be elaborated into a marking grid. Finally, components of grades 
will be weighted before being added together to reflect their relative importance in the assessment program. Using numerical ranges gives the impression of precision and the system is easy to make operational."

Each rubric has a large number of assignments related to the design projects and it must define the criteria. In order to raise the student's opportunities to show his/her skills and gain more chances to improve grades, the formative evaluation will extend to include more tasks. But in the opposite, the additional objectives are expressed for each task, the more they will operate lonely and will retreat from the overall configuration that shapes a unit of what the students are supposed to do. Since all criteria sorts are not the same, there is no requirement for the number of criteria to be the same on various assignments. Truth be told, these are titles which are expected from students to do, so as to elaborate the outline of course targets for assessors.

"On the other hand, according to the main focus of education process in a certain period, different priorities with different attention portion will be dedicated to each objective. This kind of precedence will import to assessment criteria and evaluation sheets [13]. Therefore, each task would have dedicated percentages to show the major and minor objectives and grade amount."

"So, it is needed to define some qualitative levels to apply as a norm to the assessment. Descriptions should have the best overall fit with the characteristics of the submitted projects. The assessor does not need to make separate decisions on a number of discrete criteria, as is usual list form. Such as little or no evidence, beginning, developing, accomplish, exemplary. However, these descriptions are very helpful and effective in appraisal system but finally the qualitative assessment should be able to be transmitted into grades and marks. So we need to coordinate this model to one of the common grading systems. But the single isolated result cannot stand alone as an achievement measurement or indicator that has a universal interpretation.'”

\section{Case Study: First-Year Students at Pharos University}

The first year in an architectural program is a period of transition for students who come from a tradition of vertical thinking raised by the education, therefore its requirements to be dismantled and a comprehensive thought process should be activated. The syllabus of the first year aims to introduce a creative stimulus.

This paper draws upon a case study of the first year architectural design assignment at Pharos University. This case study has various objectives and expectations to evaluate the student's product and different assignments are obligatory. These assignments aligned with the course objectives are dependent on some practical needs and some personal standards. Students are required to relate their space of studio to human needs and visual characteristics by designing a small compact unit for each student to achieve his/her needs. So, they can use this compact unit to organize the internal space of their studio in order to cope with different uses such as drawing, computerizing, cutting and pasting, storing.

\subsection{Teaching/Learning the Objectives}

The assignment has been designed to provide an authentic and engaging learning experience for the student, incorporating peer-learning, real-world problem, and group working to produce a varied portfolio of student work in order to bring the relation and interest to the student's learning, the principles of constructive alignment are also incorporated into the curriculum design. Additionally, the definition of different tasks (their scale, title, objectives) is very important to transmit a new knowledge and experience based on learned related topics. The assessment tasks should reflect realistic problems whenever possible to improve deep learning. Students are introduced to architecture as the spatial 
construction of relationships through the act of making things and revising them. This iterative process of making has consequences on the students design processes. The act of making is central to this creative process. Drawing and modeling are introduced as constructive acts. Students are asked to develop drawings and models that are consistent with the spatial aspirations of their work and as part of the generative process itself.

The exercise takes 6 weeks (Fig.1):

- The first week: following up the lecture on orthographic projection and how to survey, the students are required to make a survey of a group work and submit complete drawings for their studio in the faculty of the engineering building. This step leads the student to understand the basics of surveying and the orthographic projection, in addition, to collaborate effectively within teams;

- The second week: following up the lecture on design principles in architecture and human needs, the students are required to think and determine what their needs in his/her architectural drawing unit and how to achieve them (in the form of freehand sketches). This step transmits a new knowledge and experience based on learned related topics and leads the student to start applying in small design problem concentrating on analyzing a specific group of needs and producing new solutions;

- The third week: following up the lecture on how to think in a creative and innovative way of problem-solving and design, the students are required to develop their sketches and make a study model for a compact architectural drawing unit in order to cope with different uses such as: drawing, computerizing, cutting and pasting, storing...). This step leads the student to apply in solving the design problem through the interactive learning and discussion;

- The fourth week: the students are required to communicate in group critique and discussion after they think about how to use their unit to organize the internal space of their studio in order to cope with different uses;

- The fifth week: the students are required to illustrate pre- and final architectural drawings that clarify the problem of design that practices the neatness and aesthetics;

- The sixth week: formative assessment for final submission for the $3 \mathrm{D}$ model and complete proper portfolio of architectural drawing.

\subsection{Assessing Students' Learning Outcomes to See How Well They Match What Was Intended}

When creating an assessment plan, tutors must think about different skills which would like the students to achieve based on the learning outcomes.

"The trick is to know what level of learning tutors are trying to achieve with their students and to assess accordingly. The level and type of skills reported through assessment will depend on the level and type of task.

There was a clear relationship between learning outcomes and assessment. So, it was possible to assess

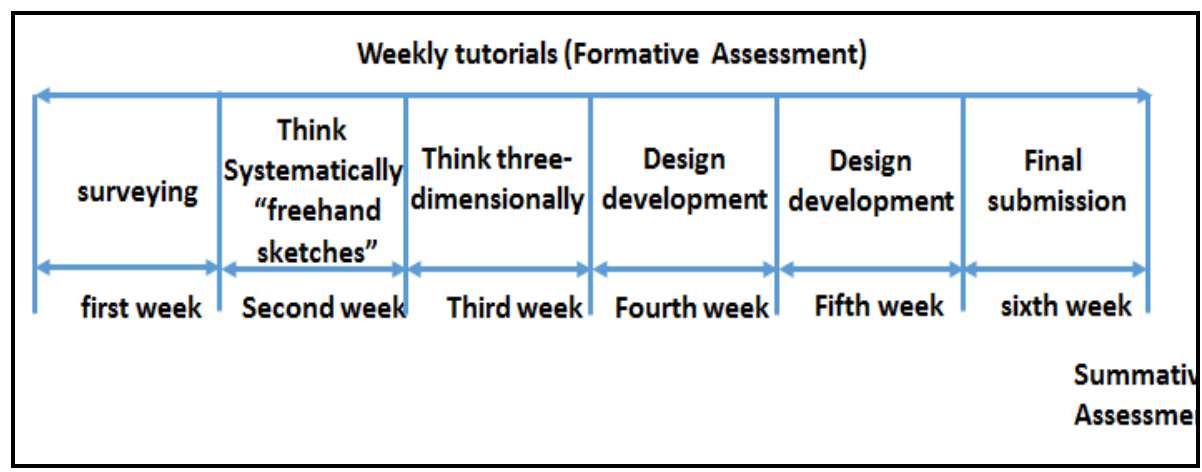

Fig. 1 Weekly tutorial planning. 
more than one learning outcome at once as long as all assessment tasks are appropriate to, and in harmony with, the learning outcomes they are meant to the assessment" [16].

The main purpose of the task was to align project content, studio design, and independent learning in a framework which would engage students in a creative learning. This creative learning was planned by the intention to shift towards the learning of functioning knowledge instead of the teaching of declarative knowledge, which can be constructively applied to student work. The weekly tasks, with clearly defined learning outcomes, directed student learning towards a set of achievable outputs which formed the foundation for the following week's work. According to the formative assessment, the total assessment workload on both teachers and learners may seem greater that experienced with one-off final assessment, but it is more equally distributed.

It was essential to use together summative and formative assessment for learning in this case study. There was set of weekly tasks that will be evaluated summatively. In all submission days, students are required to submit certain drawings which include plans, sections, evaluations, perspectives and 3D models.

Extensive formative feedback delivers the data to allow students to direct their own learning; reviews, tutorials and studio attendance and practice allow students rich opportunities for peer learning and self-assessment (Fig. 2). This opulent balance of meaning, practice, community and identity establishes an effective "community of learning" in the architectural studio.

The assignment described as a progression of understanding how simple relationships develop into more complex ones. Although the word "skill" is used to describe aspects of teaching in the first year, one could add that craft, precision, the integrity of thought and action are equally important pedagogical goals. Implicit in this is the belief that the precision of thought is directly contingent on the precision of making, and vice-versa. However, this should not exclude the freedom to engage in a process of experimentation, where students are given the space to make mistakes. Freedom and flexibility are maintained within the creative process through the studio exercises, students are introduced to a basic design question and way of initiating a response through material and space investigations. The learning objective of the tasks is to arouse the student's sensibilities for making through an iterative process of formalizing ideas (Fig. 3).

\subsection{Aligning Teaching Criteria-Based Assessment}

The tutors addressed the form of a criteria-based module which shows how marks and grades will be awarded in Table 1. "When designing a module, it is

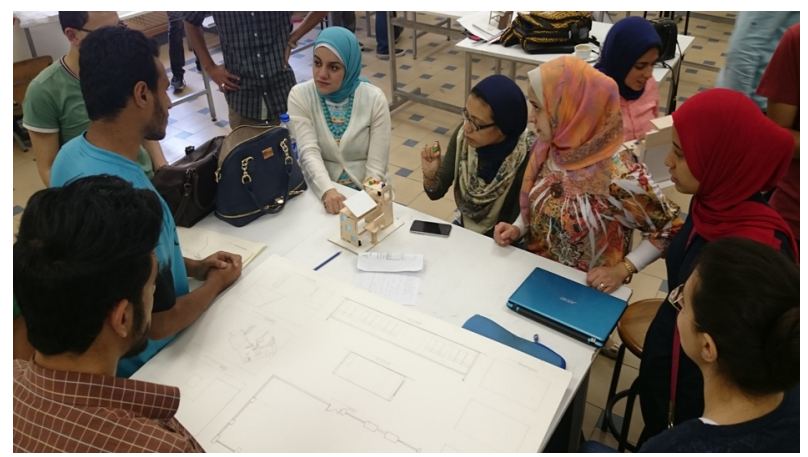

Fig. 2 Extensive formative feedbacks.

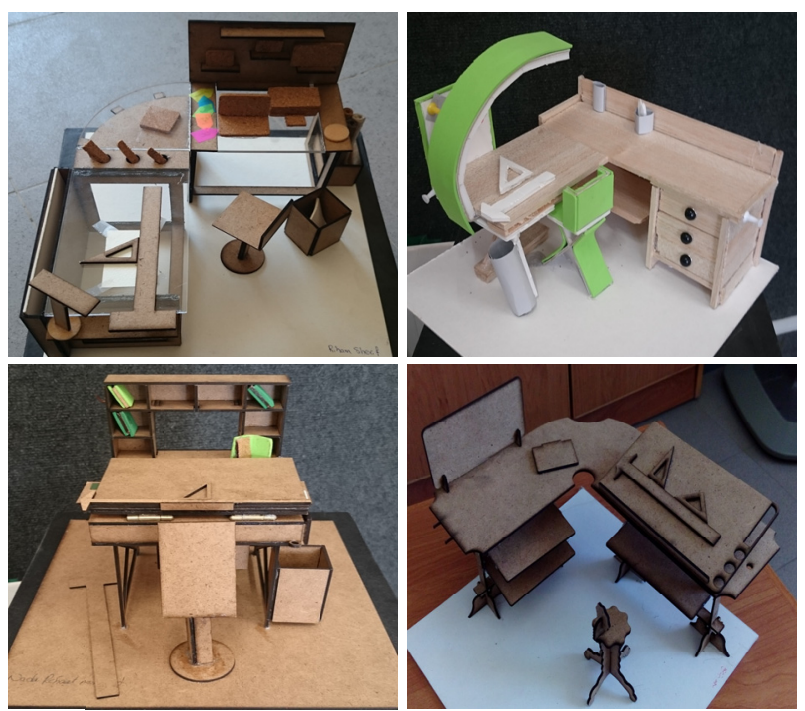

Fig. 3 Examples of student work. 
Table 1 The form of criteria-based module which shows how marks and grades will be awarded.

\begin{tabular}{|c|c|c|c|c|c|c|c|}
\hline Week & Learning outcomes & Criterion & Poor & Average & Good & Excellent & $\begin{array}{l}\text { Final } \\
\text { grade }\end{array}$ \\
\hline \multirow{3}{*}{1} & \multirow{3}{*}{$\begin{array}{l}\text { - Understand the } \\
\text { basics of surveying } \\
\text { and the orthographic } \\
\text { projection; } \\
\text { - Produce } \\
\text { architectural drawings } \\
\text { using traditional } \\
\text { techniques; } \\
\text { - Collaborate } \\
\text { effectively within } \\
\text { teams. }\end{array}$} & $\begin{array}{l}\text { Surveying } \\
\text { Process } 40 \%\end{array}$ & $\begin{array}{l}\text { Limited understanding of } \\
\text { surveying process resulting in } \\
\text { largely unsuccessful } \\
\text { architectural drawing. } \\
\text { Significant problems with } \\
\text { scale, sequence and dimension }\end{array}$ & $\begin{array}{l}\text { Basic functional } \\
\text { understanding of surveying } \\
\text { process resulting in } \\
\text { fundamentally architectural } \\
\text { drawings. Modest problem } \\
\text { with scale, sequence and } \\
\text { dimension }\end{array}$ & $\begin{array}{l}\text { A Clear understanding of } \\
\text { surveying process resulting } \\
\text { in successful architectural } \\
\text { solutions. Minor problems } \\
\text { with scale, sequence and } \\
\text { dimension }\end{array}$ & $\begin{array}{l}\text { Advanced understanding } \\
\text { surveying process resulting } \\
\text { in exemplary architectural } \\
\text { drawings. Effective use of } \\
\text { scale, sequence and } \\
\text { dimension }\end{array}$ & \multirow{3}{*}{$10 \%$} \\
\hline & & $\begin{array}{l}\text { Complete } \\
\text { drawings } 40 \%\end{array}$ & $\begin{array}{l}\text { Significant problems with } \\
\text { presentation techniques } \\
\text { resulting in unsuccessful level } \\
\text { of presentable drawings }\end{array}$ & $\begin{array}{l}\text { Basic competence in } \\
\text { presentation techniques } \\
\text { resulting in an acceptable } \\
\text { level of presentable drawings }\end{array}$ & $\begin{array}{l}\text { Advanced achievement in } \\
\text { presentation techniques } \\
\text { resulting in successful } \\
\text { presentable drawings }\end{array}$ & $\begin{array}{l}\text { Exemplary achievement in } \\
\text { presentation techniques }\end{array}$ & \\
\hline & & $\begin{array}{l}\text { Communication } \\
20 \%\end{array}$ & $\begin{array}{l}\text { A poor verbal communication } \\
\text { inhibiting discussion beyond } \\
\text { the rudimentary level }\end{array}$ & $\begin{array}{l}\text { Verbal communication } \\
\text { understandable resulting in } \\
\text { basic discussion of task }\end{array}$ & $\begin{array}{l}\text { Verbal communication well } \\
\text { planned and executed and } \\
\text { effective resulting }\end{array}$ & $\begin{array}{l}\text { Verbal presentation } \\
\text { resulting in highly effective } \\
\text { design communication of } \\
\text { clarity, detail, and precision }\end{array}$ & \\
\hline \multirow{2}{*}{2} & \multirow{2}{*}{$\begin{array}{l}\text { - Understand the } \\
\text { Principles of } \\
\text { architectural design \& } \\
\text { human needs; } \\
\text { - Think systematically } \\
\text { about the small } \\
\text { problem and human } \\
\text { need and perform } \\
\text { freehand sketch } \\
\text { drawings. }\end{array}$} & $\begin{array}{l}\text { Thinking } \\
\text { Process } 40 \% \\
\end{array}$ & $\begin{array}{l}\text { Regularly fails to meet weekly } \\
\text { progress, attendance and } \\
\text { participation requirements }\end{array}$ & $\begin{array}{l}\text { Regularly meets weekly } \\
\text { progress, attendance and } \\
\text { participation requirements }\end{array}$ & $\begin{array}{l}\text { Consistently meets all } \\
\text { weekly progress, attendance } \\
\text { and participation } \\
\text { requirements }\end{array}$ & $\begin{array}{l}\text { Consistently fulfills and } \\
\text { exceeds all weekly progress, } \\
\text { attendance and participation } \\
\text { requirements }\end{array}$ & \multirow{2}{*}{$10 \%$} \\
\hline & & $\begin{array}{l}\text { Communication } \\
20 \%\end{array}$ & Poor verbal communication & $\begin{array}{l}\text { Verbal communication } \\
\text { understandable }\end{array}$ & $\begin{array}{l}\text { Verbal communication well } \\
\text { planned }\end{array}$ & $\begin{array}{l}\text { Verbal presentation } \\
\text { resulting in highly effective } \\
\text { design }\end{array}$ & \\
\hline \multirow[t]{2}{*}{$\begin{array}{l}3 \\
4 \\
5\end{array}$} & \multirow{2}{*}{$\begin{array}{l}\text { - Think } \\
\text { three-dimensionally in } \\
\text { a creative and } \\
\text { innovative way in } \\
\text { order to solve a small } \\
\text { design problem; } \\
\text { - Examine an ability } \\
\text { to produce precise } \\
\text { expressive illustration } \\
\text { and interpretation of } \\
\text { simple design ideas; } \\
\text { - Communicate in } \\
\text { group critique and }\end{array}$} & $\begin{array}{l}\text { Development of } \\
\text { design idea } 40 \% \\
\end{array}$ & $\begin{array}{l}\text { Regularly fails to meet weekly } \\
\text { progress, attendance and } \\
\text { participation requirements. } \\
\text { Does not document or respond } \\
\text { to critical input from class } \\
\text { presentations in design } \\
\text { iterations }\end{array}$ & $\begin{array}{l}\text { Regularly meets weekly } \\
\text { progress, attendance and } \\
\text { participation requirements. } \\
\text { Usually shows evidence of } \\
\text { critical response through a } \\
\text { basic level of iterative design } \\
\text { development }\end{array}$ & $\begin{array}{l}\text { Consistently meets all } \\
\text { weekly progress, attendance } \\
\text { and participation } \\
\text { requirements. Consistently } \\
\text { shows evidence of critical } \\
\text { response iterative design } \\
\text { development }\end{array}$ & $\begin{array}{l}\text { Consistently fulfills and } \\
\text { exceeds all weekly progress, } \\
\text { attendance and participation } \\
\text { requirements. Unfailingly } \\
\text { shows evidence of } \\
\text { self-disciplined critical } \\
\text { response through exemplary } \\
\text { iterative design } \\
\text { development }\end{array}$ & \multirow{2}{*}{$40 \%$} \\
\hline & & $\begin{array}{l}\text { Drawings and } \\
\text { study model } \\
40 \%\end{array}$ & $\begin{array}{l}\text { Unable to complete design } \\
\text { solutions. Significant } \\
\text { problems with presentation } \\
\text { materials and/or techniques }\end{array}$ & $\begin{array}{l}\text { Basic competence in } \\
\text { presentation and techniques } \\
\text { resulting in an acceptable } \\
\text { level of design }\end{array}$ & $\begin{array}{l}\text { Advanced achievement in } \\
\text { presentation resulting in } \\
\text { successful design } \\
\text { communication of }\end{array}$ & $\begin{array}{l}\text { Exemplary presentation and } \\
\text { verbal presentation resulting } \\
\text { in highly effective design } \\
\text { communication of clarity, }\end{array}$ & \\
\hline
\end{tabular}




\begin{tabular}{|c|c|c|c|c|c|c|c|}
\hline & \multirow{3}{*}{ discussion. } & & \multirow[b]{2}{*}{$\begin{array}{l}\text { resulting in unsuccessful level } \\
\text { of design communication }\end{array}$} & \multirow[b]{2}{*}{$\begin{array}{l}\text { communication of general } \\
\text { completeness. Presentation } \\
\text { materials showing basic } \\
\text { elements of design organized } \\
\text { and comprehensible }\end{array}$} & \multirow[b]{2}{*}{$\begin{array}{l}\text { systematic consistency } \\
\text { Presentation materials } \\
\text { comprehensive, detailed and } \\
\text { well organized with } \\
\text { minimal minor errors } \\
\end{array}$} & \multirow[b]{2}{*}{$\begin{array}{l}\text { detail, and precision. } \\
\text { Presentation materials at } \\
\text { portfolio quality suitable for } \\
\text { transfer. No errors or } \\
\text { omissions }\end{array}$} & \\
\hline & & & & & & & \\
\hline & & $\begin{array}{l}\text { Communication } \\
20 \%\end{array}$ & $\begin{array}{l}\text { A poor verbal communication } \\
\text { inhibiting discussion beyond } \\
\text { the rudimentary level }\end{array}$ & $\begin{array}{l}\text { Verbal communication } \\
\text { understandable resulting in } \\
\text { basic discussion of task }\end{array}$ & $\begin{array}{l}\text { Verbal communication well } \\
\text { planned and executed and } \\
\text { effective resulting }\end{array}$ & $\begin{array}{l}\text { Verbal presentation } \\
\text { resulting in highly effective } \\
\text { design communication of } \\
\text { clarity, detail, and precision }\end{array}$ & \\
\hline \multirow{3}{*}{$\begin{array}{l}\text { Final } \\
\text { submis } \\
\text { sion }\end{array}$} & \multirow{3}{*}{$\begin{array}{l}\text { - Adopt innovative } \\
\text { design ideas and } \\
\text { concepts; } \\
\text { - Practice the neatness } \\
\text { and aesthetics; } \\
\text { - Communicate in } \\
\text { group critique and } \\
\text { discussion of } \\
\text { formative assessment }\end{array}$} & $\begin{array}{l}\text { Design solution } \\
40 \%\end{array}$ & $\begin{array}{l}\text { Does not attempt or is unable } \\
\text { to complete design solutions. } \\
\text { Unsuccessful design solution } \\
\text { due to lack of creative use of } \\
\text { the concept, limited } \\
\text { exploration of technique } \\
\text { and/or application of } \\
\text { principles }\end{array}$ & $\begin{array}{l}\text { Fundamentally sound design } \\
\text { solution with moderately } \\
\text { creative use of the concept, } \\
\text { fundamentally appropriate } \\
\text { technique, and adequate } \\
\text { application of principles }\end{array}$ & $\begin{array}{l}\text { Interesting design solution } \\
\text { showing consistently } \\
\text { creative development of the } \\
\text { concept, original } \\
\text { development of technique } \\
\text { and original application of } \\
\text { principles }\end{array}$ & $\begin{array}{l}\text { Compelling design solution } \\
\text { showing the highly original } \\
\text { creative development of the } \\
\text { concept, innovative } \\
\text { application of techniques } \\
\text { and exemplary use of } \\
\text { principles }\end{array}$ & \multirow{3}{*}{$40 \%$} \\
\hline & & $\begin{array}{l}\text { Presentation } \\
20 \% \\
\end{array}$ & $\begin{array}{l}\text { Major errors, consistency or } \\
\text { quality problems in drawings, } \\
\text { process, and models }\end{array}$ & $\begin{array}{l}\text { No major errors, omissions, } \\
\text { consistency or quality } \\
\text { problems in drawings or } \\
\text { models }\end{array}$ & $\begin{array}{l}\text { Minor errors and requiring } \\
\text { no further explanation }\end{array}$ & No errors or omissions & \\
\hline & & $\begin{array}{l}\text { Communication } \\
20 \%\end{array}$ & $\begin{array}{l}\text { A poor verbal communication } \\
\text { inhibiting discussion beyond } \\
\text { the rudimentary level }\end{array}$ & $\begin{array}{l}\text { Verbal communication } \\
\text { understandable resulting in } \\
\text { basic discussion of the design } \\
\text { solution }\end{array}$ & $\begin{array}{l}\text { Verbal communication well } \\
\text { planned and executed and } \\
\text { effective resulting in further } \\
\text { discussion of the solution }\end{array}$ & $\begin{array}{l}\text { Verbal presentation } \\
\text { resulting in highly effective } \\
\text { design communication of } \\
\text { clarity, detail, and precision }\end{array}$ & \\
\hline Total & & & & & & & $100 \%$ \\
\hline
\end{tabular}


Table 2 A checklist for quality in student assessment.

\begin{tabular}{lll}
\hline A checklist for quality in student assessment & Yes & No \\
\hline Is the assessment aligned with the aims? & $\sqrt{ }$ \\
Is the assessment aligned with the intended learning outcomes? & $\sqrt{ }$ \\
Is the assessment aligned with the methods of teaching? & $\sqrt{ }$ \\
Are the methods of assessment chosen correctly? & $\sqrt{ }$ \\
Are the methods of assessment diverse? & $\sqrt{ }$ \\
Is formative assessment used? & $\sqrt{ }$ \\
Are you clear on what exactly is being evaluated? & $\sqrt{ }$ \\
Do the formative assessments take place within the program assessment requirements? & $\sqrt{ }$ \\
Are the normal progressions from junior to senior status handled with? & $\sqrt{ }$ \\
Are award types easy to understand? How will assessments be marked (pass/fail/grade/feedback, etc.)? & $\sqrt{ }$ \\
Have any consideration to the chance of group or peer assessment? & $\sqrt{ }$ \\
Have you chosen a clear assessment criterion or suitable scoring grids? & $\sqrt{ }$ \\
Have you considered evaluation strategies to on reflect on assessment? & \\
\hline
\end{tabular}

important to understand and be able to clearly communicate to the student what that module is intended to achieve, what the student should be able to do and submit until completing it, and what they will have to explain in order to exceed it. Designing a criteria-based module using a learning outcomes approach recognizes the need to plan assessment as part of a whole experience. The way of assessment is aligned with the aims, outcomes, and the teaching/learning methods adopted" [13].

Scoring grids are designed for this assignment as an efficient assessment practice. They are used by assessors to assess fairly and efficiently, develop and improve student criticism. Staff designed the assessment grid which offers a complete list of criteria that can be tailored to suit the course. Simply they select the criteria/descriptors wish to use for an assessment related to the course and create the grid.

Once the learning outcomes have been clearly defined, it becomes easier to develop the assessment methods to determine whether these learning outcomes have been met. When choosing assessment items, it is important to consider the immediate task of assessing student learning within the context of the module, but also keep in mind the broader aims of the course and the qualities of the graduating student.

In order to provide a fair and transparent assessment strategy within modules and across the course, it is fundamental that both students and staff are clear on what students are expected to do, the circumstances in which they are asked to do it and how the marks are going to be an award.

Tutors used the following checklist as shown in Table 2 to access the assessment plan, in order to ensure that the assessment plan is very effective in the learning process and improvement of the quality of student learning.

\section{Conclusions}

The well-designed assessment included the methods and timing which send important messages to students. So tutors need to think about these messages when creating the assessment plans. They need to pay attention to priorities of learning, create perfect and open learning outcomes and assess suitably.

Continuous assessment can offer a more dependable evaluation of a learner's skills and the indirect way can measure a student's capability to manage time and handle stress. Suitable feedback is a significant part of constant assessment as it tells the tutor on how well students are moving ahead and how they can develop. The application of a complete educational process with critique session and criteria-based assessment has a very significant function. Both methods are very helpful in the 
learning process of students because students need to consult with critique session gradual and continuous. Then the students were satisfied with the assessment that has been defined as a criteria-based assessment. The students know the strategies and methods of learning that they must use to get good grades.

\section{References}

[1] Utaberta, N., and Badiossada, H. 2012. "Aligning Assessment with Learning Outcomes." Procedia-Social and Behavioral Sciences 60: 225-35.

[2] Crowther, P. 2010. "Assessing Architectural Design Processes of Diverse Learners." In Proceedings of the ATN Assessment Conference, 24-33.

[3] Biggs, J. B. 2003. "Aligning Teaching and Assessment to Curriculum Objectives." 2nd ed. Presented at Teaching and Learning in Higher Education: New Trends and Innovations, University of Aveiro, April 13-17, 2003.

[4] Holgate, P., and Roberts, S. 2012. "Programming the Program: Pacing the Curriculum in Architectural Education Programming the Program: Pacing the Curriculum in Architectural Education." Working Paper Series: Interdisciplinary Studies in the Built and Virtual Environment 1 (2): 194-208.

[5] Rust, C. 2002. "The Impact of Assessment on Student Learning." Active Learning in Higher Education 3 (2): 145-58.

[6] Yam, L. H. S., and Peter, R. 2010. "Implementing a Project-Based Learning Approach in an Introductory Property Course." In Proceedings of the 16th Pacific Rim Real Estate Society Conference, 1-19.

[7] James, R., McInnis, C. and Devlin, M. 2008. "Assessing Learning in Australian Universities". Accessed October 19, 2008. http://www.cshe.unimelb.edu.au/assessing learning.
[8] Hickman, R. 2007. "Whipped-Fancying and Other Vices: Re-evaluating Assessment in Art and Design." In The Problem of Assessment in Art and Design, edited by Raymend, T. Bristol: Intellect Books.

[9] Brown, S. 2008. "Fit-for-Purpose Assessment." In Proceedings of the ATN Assessment Conference: Engaging Students in Assessment, University of South Australia, Adelaide, Paper 15, 1-16.

[10] Çıkıúa, Ù., and Ela, Ç. 2009. "Problematization of Assessment in the Architectural Design Education: First Year as a Case Study." Procedia Social and Behavioral Sciences 1: 2103-10.

[11] Holgate, P. 2008. "Assessment for Learning in Architectural Design Programs." Northumbria Working Paper Series: Interdisciplinary Studies in the Built and Virtual Environment 1 (2): 194-208.

[12] Bridges, A. 2009. "A Critical Review of Problem-Based Learning in Architectural Education." In Proceedings of the CAADe Conference, 182-9.

[13] Utaberta, N., and Badiossadat, H. 2012. "A Comprehensive Learning of Architecture Education: Understanding Critique Session as Learning Process and Criteria Based Assessment in the Architecture Design Studio." In Proceedings of the 6th International Forum on Engineering Education (IFEE 2012), 21-32.

[14] Dunn, L., Morgan, C., O'Reilly, M., and Parry, S. 2005. The Student Assessment Handbook: New Directions in Traditional and Online Assessment. Abingdon: RoutledgeFalmer.

[15] Hassanpour, B., and Utaberta, N. 2012. "Critical Analysis of Criteria-Based Assessment and Grading in Architecture Education. Universiti Kebangsaan Malaysia as Case Study." Research Journal of Applied Sciences, Engineering and Technology 4 (14): 2046-54.

[16] Farrell, O. C. 2016. "Enhancing Student Learning through Assessment." Trinity College Dublin Working Paper: A Toolkit Approach: 1-24. 